\title{
РОЛЬ МАТРИКСА СОЕДИНИТЕЛЬНОЙ ТКАНИ В ОБЕСПЕЧЕНИИ ФУНКЦИОНАЛЬНОЙ АКТИВНОСТИ ЭНДОТЕЛИЯ У БЕРЕМЕННЫХ
}

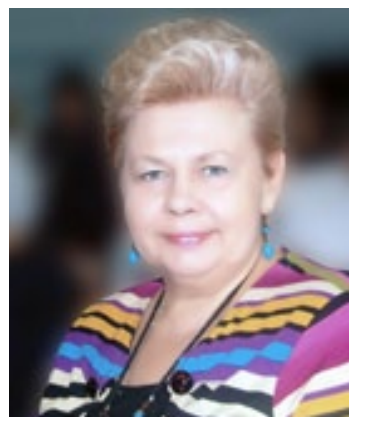

О. В. ГРИЩЕНКО д.мед.н., профессор, декан педиатрического факультета Харьковской академии последипломного образования

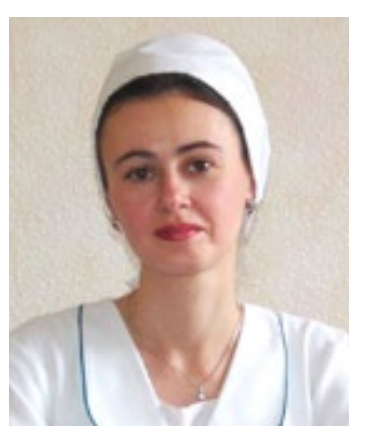

A. В. СТОРЧАК к.мед.н., доцент, кафедра педиатрии, акушерства и гинекологии Факультета фундаментальной медицины Харьковского национального университета им. В.Н. Каразина

\section{БУЙ СОН ТОАН}

аспирант касредры педиатрии, акушерства и гинекологии Факультета фундаментальной медицины Харьковского национального университета им. В.Н. Каразина
Б лагодаря запрограммированной природой изменчивости и повсеместному присутствию в организме (более 85\% массы тела), соединительная ткань осуществляет большое количество фрункций, среди которых главная - поддержание гомеостаза организма. Соединительную ткань характеризуют универсальность, специализация, многокомпонентность, полиморфизм клеточных систем, полифункциональность, высокая способность к адаптации $[11,16,20,30]$. Она состоит из клеточных элементов, волокнистых структур и основного вещества: клеточные элементы представлены фрибробластами, ретикулярными, тучными, плазматическими клетками, макрофагами; волокнистые структуры составляют коллагеновые, эластические и ретикулярные волокна. Основным компонентом соединительной ткани является его основное вещество (матрикс), включающий тканевую (внеклеточную) жидкость и макромолекулы, преимущественно полисахаридов (протеогликанов, гликопротеинов и их структурных компонентов - гликозаминогликанов (ГАГ), образующих золь или гель. Наибольшую физиологическую значимость имеют такие ГАГ, как гиалуроновая кислота, хондроитин сульфрат, кератан сульфрат, гепарин, гепаран сульфрат и дерматан сульсрат. Межклеточный матрикс, окружающий клетки, влияет на их прикрепление, развитие, пролиферацию, организацию и метаболизм. Элементы, формирующие матрикс соединительной ткани (МСТ), немногочисленны и с достаточным постоянством определяются во всех разновидностях соединительной ткани, что является свидетельством системности этих тканей, объединенных общим мезенхимальным происхождением и принципами структуры и функции $[4,7,19,20,30]$.

Физиологическое течение процесса гестации обеспечивается благодаря запрограммированной природой изменчивости соединительнотканных структур организма беременной, которые связаны с иммуноадаптационными перестройками, распространяющимися прежде всего на матрикс матки, сосуды эндометрия и миометрия. Рост матки, эмбриогенез и фетогенез представляют собой нарастающее по объему “строительство" тканей, богатых экстацеллюлярным матриксом. Кроме того, в ходе внутриутробного онтогенеза МСТ плода и его провизорных органов претерпевают кардинальные изменения в своем составе, меняют в тканях соотношение коллагенов, гликозаминогликанов. Постоянное нарастающее ремоделирование МСТ в организме беременной и у плода считается ключевым биологическим процессом во время гестации $[4,8,15,16,26$, 33], поэтому патогенез гестационной патологии нельзя рассматривать только с позиций органной патологии, так как функция органа определяется фрункцией клеток, а их фрункции и взаимодействие - матриксным окружением.

Физиологическое течение гестации адекватно гемодинамике в фретоплацентарном комплексе, которое складывается из кровоснабжения маточно-плацентарной области, кровоснабжения decidua parietalis и плодово-плацентарного кровотока. Поскольку общая площадь поперечного сечения микроциркуляторного русла по сравнению с другими частями сосудистого русла наибольшая и на долю артериол и мелких артерий приходится около $70 \%$ общего сосудистого сопротивления кровотоку, то управление микроциркуляцией влияет на гемодинамику в целом. Кровенаполнение микроцируляторного русла обеспечивается резистивными сосудами, имеющими выраженный мышечный слой. Эти сосуды могут значительно изменять свой просвет, регулируя объем притекающей крови и скорость кровотока. Для поддержания стабильного равновесия в системе гемодинамики и оптимальных условий для транскапиллярного обмена В микроциркуляторном русле необходимы определенный уровень гидростатического давления в сосуде, непрерывность кровотока, отсутствие повреждений сосудистой стенки. Гемодинамическая стабильность происходит за счет эндотелия [5, 12, 21].

По современным представлениям, эндотелий не просто один из клеточных слоев сосудистой стенки, а активный орган, самый большой в теле человека (1,8 кг), дифффузно рассеянный по всем тканям. Эндотелий синтезирует различные типы коллагенов, эластин, фибронектин, составляющие основу сосудистой стенки, ГАГ - основу межклеточного матрикса, а также субстанции, важные для контроля реологических свойств крови, регуляции тонуса сосудов, фильтрационной функции почек, сократительной активности сердца, метаболического обеспечения мозга. Эндотелий контролирует дифффузию воды, ионов, продуктов метаболизма, рост клеток (табл. 1), реагирует на механическое воздействие текущей жидкости, кровяное давление и ответное напряжение, создаваемое мышечным слоем сосуда, чувствителен к химическим и структурным повреждениям, которые могут приводить к повышенной агрегации и адгезии циркулирующих клеток, развитию тромбоза, оседанию липидных конгломератов $[2,5,6,21]$. 
Существует два варианта фризиологической секреторной активности эндотелия: базальная, или постоянная (синтез оксида азота [NO]), простациклина), и стимулированная секреция - выделение биологически активных веществ при стимуляции или повреждении эндотелия (фрактор Виллебранда, активатор тканевого плазминогена и др.). Стимулированная секреция эндотелия характеризуется выделением биологически активных веществ, почти несинтезируемых в фризиологических условиях [3, $6,10,14,28]$.

Существует три основных фрактора, способных стимулировать синтетическую активность эндотелия: изменение скорости кровотока (увеличение напряжения сдвига при повышении скорости кровотока в условиях повышенного АД) повреждающее эндотелий; повышение уровня нейрогормонов (катехоламинов, вазопрессина, ацетилхолина, брадикинина, аденозина, гистамина и др.); активация тромбоцитов с выделением серотонина АДФ, тромбина [6, 25].

Здоровый эндотелий поддерживает интактной люминальную поверхность и регулирует антикоагулянтные, фибринолитические и антитромботические механизмы. В физиологических условиях эндотелиальный баланс сдвинут в сторону поддержания вазодилатации (за счет постоянного высвобождения низкого уровня NO) - готовности противодействовать усилению тонуса, что объясняется постоянным напряжением в циркуляторной системе и созданием перфузионного градиента, благодаря которому происходит обмен в тканях. При воздействии различных повреждающих фракторов (механических, инфекционных, обменных, иммунокомплексных и т.п.) способность эндотелиальных клеток освобождать релаксирующие факторы уменьшается, тогда как образование сосудосуживающих фракторов сохраняется или увеличивается, т.е. формируется состояние, определяемое как диссункция эндотелия [2, 6, 10, 14, 25, 28].

В развитии эндотелиальной дисфункции происходит закономерная смена фраз: повышенная секреторная активность эндотелиоцитов - фраза компенсации в условиях возрастающих требований к сосудистой системе; нарушение баланса эндотелиальной секреции (промежуточная фаза) - сдвиг в системе продукции и инактивации, нарушение собственно барьерной фрункции эндотелия, повышение его проницаемости для моноцитов, провоспалительных цитокинов, эндотелина-1 и др.; структурно-метаболическое истощение эндотелия - функциональное угасание, гибель и десквамация клеток, угнетение их регенерации (фраза декомпенсации) [14, 28].

При фризиологическом течении гестации сохраняется преобладание вазодилатирующих субстанций, однако с некоторым возрастанием уровня маркеров повреждения эндотелия (эндотелина-1, простациклина, тромбоксана, фибронектина, тромбомодулина, NO) и увеличением

\begin{tabular}{|c|c|}
\hline стимуляторы & ИНГИБИТОРЫ \\
\hline \multicolumn{2}{|c|}{ Факторы сокращения сосудистой стенки } \\
\hline $\begin{array}{l}\text { Эндотелин } \\
\text { Ангиотензин-II } \\
\text { Тромбоксан (ТХА2) } \\
\text { Простагландин Н2 }\end{array}$ & $\begin{array}{l}\text { NO } \\
\text { Эндотелин } \\
\text { Простациклин (PGI2) } \\
\text { Эндотелиновый фрактор деполяризации (EDHF) }\end{array}$ \\
\hline \multicolumn{2}{|l|}{ Факторы гемостаза } \\
\hline $\begin{array}{l}\text { Тромбоцитарный ростовой фактор (PDGF) } \\
\text { Ингибитор активатора плазминогена } \\
\text { Фактор Виллебранда } \\
\text { Ангиотензин-IV } \\
\text { Эндотелин-1 }\end{array}$ & $\begin{array}{l}\text { NO } \\
\text { Тканевой активатор плазминогена (TPA) } \\
\text { Простациклин (PGI2) }\end{array}$ \\
\hline \multicolumn{2}{|l|}{ Факторы, влияющие на рост сосудов } \\
\hline $\begin{array}{l}\text { Эндотелин-1 } \\
\text { Ангиотензин-ІІ } \\
\text { Супероксидные радикалы }\end{array}$ & $\begin{array}{l}\text { NO } \\
\text { Простациклин (PGI2) } \\
\text { С-натриуретический пептид }\end{array}$ \\
\hline \multicolumn{2}{|l|}{ Факторы, влияющие на воспаление } \\
\hline $\begin{array}{l}\text { Фактор некроза опухоли (TNF-a) } \\
\text { Супероксидные радикалы }\end{array}$ & NO \\
\hline
\end{tabular}

срока гестации, что можно расценивать как первую (компенсированную) фазу эндотелиальной диссрункции [2, 9, 22].

ТАБЛИЦА 1. ФАКТОРЫ, СИНТЕЗИРУЕМЫЕ В ЭНДОТЕЛИИ И РЕГУЛИРУЮЩИЕ ЕГО ФУнКцию

Эндотелиальная дисфункция является основным звеном в патогенезе гестоза, который стабильно занимает третье место среди причин материнской смертности в Украине. Возникшая во время беременности эндотелиальная дисфункция становится основой формирования соматической патологии вне беременности. Условием для развития эндотелиальной диссрункции во время беременности может служить генетическая предрасположенность (изменения 7q23 - гена ангиотензинпревращающего фермента, NOS3 и NOS2-генов NO-синтетазы, AT2P1 - гена рецептора ангиотензина II, системы антигенов гистосовместимости), гемодинамические нарушения, обусловленные нарушением инвазии цитотрофобласта и неполноценной гестационной перестройкой спиральных артерий, плацентарная ишемия и оксидативный стресс $[1,9,15,17,18]$.

Эндотелиальная дисфункция при гестозе проявляется нарушенной способностью эндотелия обеспечивать эндотелийзависимую вазодилатацию вследствие дисбаланса синтеза и высвобождения сосудорасширяющих, антиагрегантных и антикоагулянтных факторов, с одной стороны, и вазоконстрикторов и проагрегантов, с другой. В первую очередь активируются тромбоциты, повышается их агрегация, повышается содержание продуктов тромбоцитарного происхождения тромбомодуляторов (тромбоксана А2, факторов Виллебранда и активации тромбоцитов, АДФ, ингибитора активации плазминогена - PAl-1), указывающих на наличие диссрункции эндотелия. Активированные тромбоциты в значительной степени способствуют генерированию тромбина, катализируя и обеспечивая фракторы для реакций гуморального коагуляционного каскада [3, 18, 22].

Большинство из функций эндотелия реализуются вследствие взаимодействия эндотелия с макромолекулами матрикса (протеогликанами, гли- 
козаминогликанами) соединительной ткани сосудистой стенки [6, 23, 27, 29-31]. ГАГ входят в состав гликокаликса эндотелия, широко представлены в субэндотелиальном слое сосудистой стенки, синтезируются эндотелием в кровь (рис. 1).

ГАГ, входящие в состав гликокаликса эндотелия, поддерживают его отрицательный заряд, регулируют проницаемость сосудистой стенки. Гликокаликс служит сетевым барьером для потока растворенных веществ, защищающим эндотелий от поражения. Протеогликаны контролируют транспорт воды, тромборезистентность и устойчивость ко многим повреждающим фракторам, в том числе к воздействию протеаз, экзо- и эндотоксинов, иммунных комплексов и др. В состав протеогликанов гликокаликса входят: гиалуроновая кислота, хондроитин сульфрат, гепаран сульфрат и дерматан сульфат [7, 23, 24, 27, 33]. Достаточная чувствительность гликокаликса к изменению окружающих условий позволяет ему служить одним из ранних маркеров клеточного фрункционирования в патологических ситуациях. Состав гликокаликса зависит от скорости синтеза эндотелием ГАГ и их шеддингом (отрывом/срезанием). Потеря гликокаликса тесно связана с эндотелиальной дисфункцией. Потеря гепаран сульфата в гликокаликсе, культуре эндотелия или гиалуроновой кислоты ведет к снижению продуцирования NO в ответ на напряжение сдвига на поверхности эндотелия. Для такого продуцирования NO гепаран сульфат играет роль механорецептора, а гиалуроновая кислота выступает биомеханическим сенсором [27, 29, 34].

ГАГ, синтезируемые в эндотелии, попадая в циркулирующую кровь, оказывают сильнейшее антитромботическое действие, восстанавливают поврежденный эндотелий. Сульфатированные ГАГ взаимодействуют с фрактором роста фибробластов, сосудисто-эндотелиальным фактором роста, чем определяют их ангиогенные эффекты [23, 24, 26].

ГАГ широко представлены и в субэндотелиальной прослойке соединительной ткани, которая состоит из ламинина, фибронектина, коллагена, витронектина, протеогликанов: версикана (хондроитин сульфата протеогликан), бигликана (хондроитин сульфрата/дерматан сульфата протеогликаны), декорина (хондроитин сульфата/дерматан сульфата протеогликаны), перлекана (гепаран сульфата протеогликан), синдекана (хондроитин сульфрата/гепаран сульфата протеогликаны). Эндотелиальный монослой клеток адгезирован на соединительнотканном матриксе, компоненты которого являются частью базальной мембраны высокой эластичности и растяжимости и синтезируются эндотелием в ходе ангиогенеза и васкулогенеза. Эндотелий зрелых сосудов способен постоянно ремоделировать экстрацеллюлярный матрикс. Протеогликан (гепаран сульфата) считается ключевым компонентом субэндотелиального матрикса, который играет важную роль в «сборке» и структуре базальной мембраны, регуляции проницаемости базальной мембраны, активности фактора роста и клеточной адгезии. Биомеханические свойства сосудистой стенки во многом определяются присутствующей в ней соединительной тканью [30, 32-34].

В литературе информации об особенностях ремоделирования МСТ у беременных крайне мало. Участие МСТ в обеспечении функциональной активности эндотелия, реологических свойств крови, сосудистой проницаемости, изучение особенностей метаболизма матрикса при эндотелиальной дисфункции позволят расширить представления о механизмах формирования гемодинамических нарушений при гестозе и усовершенствовать их профрилактику.

Цель исследования состояла в установлении особенности метаболизма МСТ при физиологической гестации и гестозе, его влияния на функциональную активность эндотелия.

\section{МАТЕРИАЛЫ И МЕТОДЫ ИССЛЕДОВАНИЯ}

Под нашим наблюдением находились 100 беременных с преэклампсией различной степени тяжести на сроках гестации 30-36 нед. В I группу вошли 50 беременных с преэклампсией легкой степени, во II - 30 женщин с преэклампсией средней степени тяжести и в III - 20 обследуемых с тяжелой преэклампсией. Для исследования отбирали пациенток с чистой формой гестоза, степень тяжести преэкламспии определяли в соответствии с рекомендациями клинических протоколов по акушерской и гинекологической помощи (согласно приказу МЗ Украины от 31.12.2004 г. № 676). В контрольную группу были включены 30 беременных, у которых гестация протекала фризиологически, за ними наблюдали в консультативной поликлинике Харьковского городского клинического родильного дома с неонатологическим стационаром в соответствии с требованиями приказа МЗ Украины от 28.12.2002 г. № 503.

Наряду с базовым обследованием, необходимым при преэклампсии, у всех пациенток исследовали метаболизм МСТ, функциональную активность и степень повреждения эндотелия, оценивали системную гемодинамику, показатели кровотока в фетоплацентарном комплексе.

Особенности метаболизма МСТ определяли по общей концентрации сульфатированных ГАГ в сыворотке крови с последующим их фрракционированием; суммарное содержание хондроитин сульфатов (г/л) по реакции с риванолом - по методу Ю.Ю. Лапса и Л.И. Слуцкого (1969) и гликопротеинов по методу Я.И. Штейнберга и О.П. Доценко. Изучали концентрацию общего, связанного и свободного $\mathrm{N}$-ацетилгликозамина в сыворотке крови беременных по методу М.Н. Штерн (1982). Определение суточной экскреции оксипролина с мочой производили спектрофротометрически по методу А.А. Крель и Л.Н. Фурцевой (1986), с использованием в качестве красителя парадиметиламинобензальдегида. Метаболизм ГАГ исследовали по уровню уроновых кислот в суточной моче по реакции с карбазолом по методу Д.В. Косягина (1988).

Оценку степени повреждения эндотелия проводили по содержанию десквамированных эндотелиоцитов в венозной крови по методике J. Hladovec (1978) в модификации Л.Г. Краснова и соавт. (2004). Вазодилатирующую способность эндотелия определяли по уровню S-нитрозотиола методом Г.Н. Близнецова и соавт. (2002), эндотелин-1 - иммуноферментным методом с помощью наборов реактивов ELISA (Канада).

Для оценки влияния эндотелиальной дисфункции на сосудистый тонус выполняли суточное мониторирование артериального давления (АД), оценивая такие параметры, как средние цифры систолического артериального давления (САД), диастолического артериального давления (ДАД) в дневные и ночные часы и в течение суток, а также вариабельность САД и ДАД в дневные и ночные часы. Выясняли время, в течение которого АД превышало критические показатели для беременной женщины (индекс времени), что выражалось в процентах от суток. В качестве критического для беременной принимали АД в дневные часы 140/85 мм рт. ст., в ночные - 120/70 мм рт. ст.

Оценку показателей гемодинамики в маточно-плацентарном и плодово-плацентарном бассейнах фретоплацентарного комплекса проводили с помощью допплерометрического исследования основных показателей, характеризующих кровоток: индекса резистентности (L. Pourcelot, 1974), пульсационного 
БЕРЕМЕННОСТЬ И РОДЫ

индекса (R. Gosling, 1975), систоло-диастолического отношения (B. Stuart, 1980) в обеих маточных артериях, артерии пуповины, средней мозговой артерии плода на ультразвуковом аппарате Voluson 730 Pro.

Для оценки внутриутробного состояния плода в антенатальном периоде проводили непрямую кардиотокографию кардиотокографом IFM Biosys Co Ltd (Корея). Полученные кардиотокограммы обрабатывали методом качественного и количественного анализов в соответствии с методикой оценки нестрессового теста по H. Krebs (1978), биофизический профиль плода оценивали по шкале A.M. Vintzilios et al. (1987).

Большинство (67\%) женщин с преэклампсией были в возрасте до 30 лет, однако тяжелые формы преэклампсии оказались типичны для пациенток старше 35 лет. Большинство (80\%) беременных, страдавших гестозом, были заняты интеллектуальным трудом. Это продолжающие учебу студентки, служащие государственных или частных компаний с высоким уровнем личной ответственности. Анализ семейного анамнеза позволил установить достоверно более высокий процент преэклампсий во время беременности у ближайших родственниц (матери, сестер), а также высокий уровень патологий сосудистой системы. У пациенток с преэклампсией выявлены разрозненные фенотипические маркеры мезенхимальной недостаточности, среди которых обращало на себя внимание поражение сосудов в виде варикозного расширения вен различной локализации, что позволяет предположить преимущественную недостаточность соединительнотканного матрикса сосудов. Гинекологический анамнез больных с преэклампсией преимущественно отягощен нарушениями регуляции менструальной функции, ведущими к формированию лютеиновой недостаточности. Для повторно беременных пациенток с преэклампсией характерно наличие в анамнезе репродуктивных потерь на ранних сроках гестации.

\section{РЕЗУЛЬТАТЫ ИССЛЕДОВАНИЯ}

Системный метаболизм МСТ у беременных с преэклампсией характеризуется высвобождением гликопротеинов, снижением при преэклампсии средней и тяжелой степени уровней сульфатированных ГАГ. Преобладание процессов деструкции в МСТ у пациенток с преэклампсией подтверждается высоким уровнем экскреции с мочой метаболитов ГАГ - уроновых кислот и маркера деградации коллагенов - оксипролина (табл. 2).

Дисбаланс во фракционном составе сульфатированных ГАГ выражался в относительном преобладании хондроитин-6-сульфрата при пропорциональном степени тяжести гестоза снижении хондроитин-4-сульфрата и фракции труднорастворимых ГАГ (гепаран сульфрата, дерматан сульфата, кератан сульфата) (рис. 1). Десицит хондроитин-

\section{ТАБЛИЦА 2}

\section{Клинические группы}

Физиологическая

Беременность $(\mathrm{n}=30)$

Преэклампсия

легкой степени $(\mathrm{n}=50)$

Преэклампсия средней

степени тяжести $(n=30)$

Преэклампсия

тяжелой степени $(\mathrm{n}=20)$

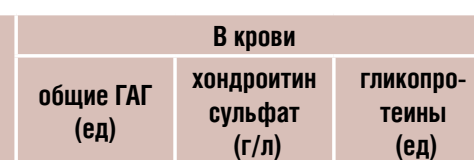

$12,6 \pm 0,4 \quad 0,105 \pm 0,03 \quad 0,35 \pm 0,06$

$12,38 \pm 0,45 \quad 0,28 \pm 0,025^{\star} \quad 0,55 \pm 0,08^{*}$

$11,79 \pm 0,35^{*} \quad 0,33 \pm 0,03^{*} \quad 0,78 \pm 0,06^{*}$

$11,47 \pm 0,35^{*} \quad 0,276 \pm 0,3^{*} \quad 0,66 \pm 0,06^{*}$

\begin{tabular}{|c|c|}
\hline \multicolumn{2}{|c|}{ В моче } \\
\hline $\begin{array}{c}\text { оксипролин } \\
\text { (мг/сут) }\end{array}$ & $\begin{array}{c}\text { уроновые } \\
\text { кислоты } \\
\text { (мг/сут) }\end{array}$ \\
\hline $26 \pm 3,50$ & $4 \pm 0,4$ \\
\hline $47,86 \pm 4,85^{*}$ & $6,44 \pm 0,46^{*}$ \\
\hline $61 \pm 5,40^{*}$ & $6,93 \pm 0,4^{*}$ \\
\hline $66,57 \pm 4,8^{*}$ & $6,43 \pm 0,4^{*}$ \\
\hline
\end{tabular}

ТАБЛИЦА 2.

СОДЕРЖАНИЕ КОМПОНЕНТОВ МСТ В КРОВИ И ЭКСКРЕЦИЯ С МОЧОЙ У БЕРЕМЕННЫХ С ПРЕЭКЛАМПСИЕЙ компонента сосудистого гликокаликса, отражают функциональное и структурное повреждение эндотелия. Кроме того, они определяют реологические свойства крови, что служит объяснением возникновения типичных нарушений гемостаза при преэклампсии, влияющей на тромбосрилию.

$\square$ Хондроитин-6-сульфат

$\square$ Хондроитин-4-сульфат

$\square$ Гепаран сульфат, гепарин, дерматан сульфат, кератан сульфат

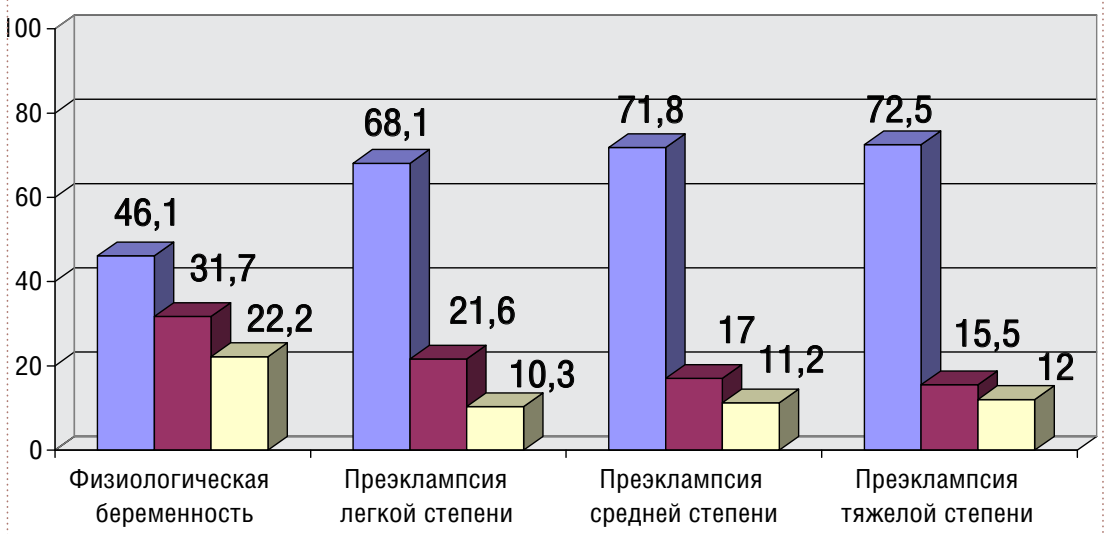

Деструкция матрикса происходила на фоне дефицита эссенциального компонента для синтеза ГАГ $\mathrm{N}$-ацетилглюкозамина (табл. 3).

Десицит связанной с белками фрракции $\mathrm{N}$-ацетилглюкозамина при преэклампсии средне-

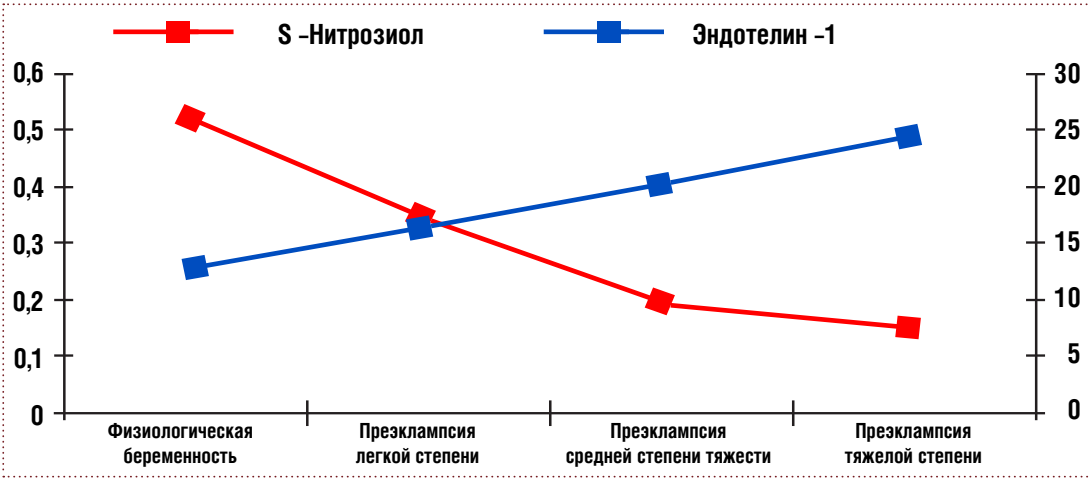

тяжелой и тяжелой степени является следствием истощения его количества в ходе борьбы с оксидативным стрессом, вызванным системным воспалительным ответом, что объясняет преобладание деструкции ГАГ над их синтезом. Таким
РИС. 1. СУЛЬФАТИРОВАННЫХ ГАГ В КРОВИ В ГРУППАХ БЕРЕМЕННЫХ (\%)

\section{логической беременности;}

- при преэклампсии легкой степени статистически достоверно $(p<0,05)$ 
ТАБЛИЦА 3.

\begin{tabular}{|l|c|c|c|c|}
\hline \multicolumn{1}{|c|}{ Показатель } & $\begin{array}{c}\text { Физиологи- } \\
\text { ческая } \\
\text { беременность, } \\
\mathbf{n = 3 0}\end{array}$ & $\begin{array}{c}\text { легкая } \\
\text { степень } \\
\mathbf{n = 5 0}\end{array}$ & $\begin{array}{c}\text { Преэклампсия } \\
\text { средняя } \\
\text { степень, } \\
\mathbf{n = 3 0}\end{array}$ & $\begin{array}{c}\text { тяжелая } \\
\text { степень, } \\
\mathbf{n = 2 0}\end{array}$ \\
\hline $\begin{array}{l}\text { Общий } \\
\text { N-ацетилглюкозамин, ммоль/л }\end{array}$ & $3 \pm 0,2$ & $2,75 \pm 0,2$ & $2,16 \pm 0,2^{*}$ & $1,84 \pm 0,15^{*}$ \\
\hline $\begin{array}{l}\text { Свободный } \\
\text { N-ацетилглюкозамин, ммоль/л }\end{array}$ & $0,38 \pm 0,1$ & $0,45 \pm 0,1$ & $0,28 \pm 0,1$ & $0,26 \pm 0,1$ \\
\hline $\begin{array}{l}\text { Связанный } \\
\text { N-ацетилглюкозамин, ммоль/л }\end{array}$ & $2,62 \pm 0,2$ & $2,30 \pm 0,2$ & $1,88 \pm 0,2^{*}$ & $1,58 \pm 0,15^{*}$ \\
\hline
\end{tabular}

ТАБЛИЦА 3.

УРОВЕНЬ ЭССЕНЦИАЛЬНОГО КОМПОНЕНТА МСТ N-АЦЕТИЛГЛЮКОЗАМИНА

В КРОВИ У БЕРЕМЕННЫХ

* отличие от показателей при

физиологической беременности

и при преэклампсии легкой степени статистически достоверно $(p<0,05)$

образом, преэклампсия средней степени тяжести сопровождается истощением регенераторных механизмов в МСТ, усуглубляемым при преэклампсии тяжелой степени.

В ходе оценки синтетической активности эндотелия установлено, что при преэклампсии легкой степени наблюдаются снижение синтеза S-нитрозотиолов (отражающее дефрицит NO) $и$

ТАБЛИЦА 4.

\begin{tabular}{|c|c|c|c|c|}
\hline \multirow{2}{*}{ Показатель } & \multirow{2}{*}{$\begin{array}{c}\text { Физиологи- } \\
\text { ческая } \\
\text { беременность, } \\
\text { n= } 30\end{array}$} & \multicolumn{3}{|c|}{ Преэклампсия } \\
\hline & & $\begin{array}{c}\text { легкая степень, } \\
\text { n = 50 }\end{array}$ & $\begin{array}{c}\text { средняя степень, } \\
\text { n = } 30\end{array}$ & $\begin{array}{c}\text { тяжелая степень, } \\
\text { n = } 20\end{array}$ \\
\hline S-нитрозотиол, ммоль/л & $0,52 \pm 0,08$ & $0,34 \pm 0,06^{*}$ & $0,19 \pm 0,06^{*}$ & $0,15 \pm 0,05^{*}$ \\
\hline Эндотелин-1, нг/мл & $12,65 \pm 2,12$ & $16,45 \pm 1,4^{*}$ & $20,30 \pm 1,65^{\star}$ & $24,42 \pm 1,54^{*}$ \\
\hline $\begin{array}{l}\text { Десквамированные } \\
\text { эндотелиоциты, '104/мл }\end{array}$ & $4,58 \pm 0,37$ & $5,45 \pm 0,4^{*}$ & $6,46 \pm 0,4^{*}$ & $6,68 \pm 0,55^{\star}$ \\
\hline
\end{tabular}

ТАБЛИЦА 4.

ПОКАЗАТЕЛИ ФУНКЦИОНАЛЬНОЙ АКТИВНОСТИ ЭНДОТЕЛИЯ У ПАЦИЕНТОК ОБСЛЕДОВАННЫХ ГРУПП (М $\pm М)$

* отличия от показателей контрольной группы, при преэклампсии легкой и средней степени тяжести статистически достоверны $(p<0,05)$

повышение синтеза эндотелина-1, что смещает регуляторные влияния на сосудистую стенку в сторону вазоконстрикции (табл. 4).

При преэклампсии среднетяжелой и тяжелой степени дисбаланс в сторону вазоконстрикции усугубляется (рис. 2). Преобладание синтеза вазоконстрикторов и повышение сосудистого сопротивления току крови вызывают повреждение эндотелиальной выстилки сосудов, что регистрируется в виде достоверного повышения при преэклампсии легкой степени количества эндотелиоцитов в венозной крови

ТАБЛИЦА 5

\begin{tabular}{|c|c|c|c|c|}
\hline \multirow[b]{2}{*}{ Показатель } & \multirow{2}{*}{$\begin{array}{c}\text { Физиологиче- } \\
\text { ская беремен- } \\
\text { ность, } \mathbf{n}=30\end{array}$} & \multicolumn{3}{|c|}{ Преэклампсия } \\
\hline & & $\begin{array}{c}\text { легкая степень, } \\
\text { n = } 50\end{array}$ & $\begin{array}{c}\text { средняя степень, } \\
\text { n = } 30\end{array}$ & $\begin{array}{c}\text { тяжелая степень, } \\
\text { n = } 20\end{array}$ \\
\hline Индекс времени САД (д), \% & $12,3 \pm 0,6$ & $26 \pm 1,1^{*}$ & $58,7 \pm 2,7^{\star \bullet}$ & $96,2 \pm 3,2^{\star \bullet \bullet}$ \\
\hline Индекс времени САД (н), \% & $25 \pm 1,6$ & $42,4 \pm 2^{*}$ & $65,5 \pm 3,2^{\star \bullet}$ & $88,0 \pm 3,4^{* \bullet \bullet}$ \\
\hline Индекс времени ДАД (д), \% & $15,3 \pm 1,1$ & $38,0 \pm 1,7^{*}$ & $66,2 \pm 3,1^{* \bullet}$ & $98,2 \pm 1,8^{* \bullet \bullet}$ \\
\hline Индекс времени ДАД (н), \% & $25,4 \pm 2$ & $65 \pm 3,2^{*}$ & $90,3 \pm 3,5^{\star \bullet}$ & $100 * \bullet$ \\
\hline
\end{tabular}

ТАБЛИЦА 5.

ИНДЕКС ВРЕМЕНИ, КОГДА АД БЕРЕМЕН НЫХ ПРЕВЫШАЕТ НОРMУ (\%)

* отличия от показателей контрольной группы статистически достовер ны $(p<0,05)$;

- отличия с показателями при преэклампсии легкой степени статистически достоверны $(\mathrm{p}<0,05)$;

• отличия от показателей при преэклампсии средней степени

статистически достоверны $(p<0,05)$ деэндотелизация артерий не только снижала потокозависимые дилататорные ответы, но и потокозависимое сокращение артерий с малым и средним уровнем миогенного тонуса. В участках, лишенных эндотелиальной выстилки, нейрогормоны, минуя эндотелий, оказывали непосредственное воздействие на гладкомышечные клетки, вызывая их сокращение.

Таким образом, преэклампсия легкой степени сопровождалась функциональными нарушениями эндотелия, при преэклампсии среднетяжелой и тяжелой степени - деэндотелизацией сосудов, что объясняет возникающую зачастую резистентность к гипотензивной терапии.

Клинической реализацией эндотелиальной дисфункции является повышение АД с высокой вариабельностью САД и ДАД, особенно в ночные часы, что свидетельствует о нарушениях в регуляции сосудистого тонуса. Эндотелиальная дисфункция была причиной ситуации, когда ночью индекс времени патологического ДАД оставался высоким вследствие непосредственного влияния вазоконстрикторов на миоциты при деэндотелизации сосуда (табл. 5). Длительные периоды повышенного АД повреждают эндотелий из-за увеличения напряжения сдвига, что еще в большей степени способствует повышению сосудистого тонуса.

У беременных с преэклампсией выявлена высокая частота патологических изменений в структуре плаценты. При этом доминировали инволютивно-дистрофические изменения: преждевременное старение плаценты, ее гипоплазия и как функциональное следствие - формирование маловодия. Частым признаком нарушения гемодинамики в межворсинчатом пространстве при преэклампсии среднетяжелой и тяжелой степени было его расширение, которое связано не с увеличением объема поступающей в межворсинчатое пространство крови, а с ее стазом и нарушением венозного оттока. Подтверждением этого служит регистрация у пациенток снижения объемной скорости кровотока в маточной артерии и ее ветвях.

Мы отдельно изучали показатели гемодинамики в маточно-плацентарном и плодово-плацентарном кровотоках. При обследовании кровотока в маточных артериях установлено, что близость плацентарной площадки вызывает асимметрию показателей. Даже у пациенток с физиологическим течением гестации прикрепление плаценты по боковой стенке матки приводило к латеризации кровотока. При преэклампсии среднетяжелой и тяжелой степени показатель латеризации кровотока был достоверно выше, причем, нарушения кровотока фриксировались на стороне, максимально приближенной к плацентарной площадке, что подтверждает мнение о первичности нарушений кровотока на уровне маточно-плацентарных артерий с неполноценной гестационной трансорормацией. 
При преэклампсии легкой степени у 19 (38 $\pm 6,86 \%)$ пациенток преобладали изменения в маточно-плацентарном кровотоке, у 12 (24 $\pm 6,04 \%)$ - в плодово-плацентарном, причем, только у 3 $(6 \pm 3,36 \%)$ беременных с преэклампсией легкой степени имело место нарушение только плодово-плацентарного кровотока, в то время как у 9 (18 $\pm 5,43 \%)$ беременных нарушения маточно-плацентарного и плодово-плацентарного кровотоков сочетались.

При преэклампсии средней степени тяжести нарушения маточно-плацентарного кровотока выявлены у 21 (70 $\pm 8,37 \%)$ беременной, что достоверно больше, чем при преэклампсии легкой степени - 19 (38 $\pm 6,86 \%),(p<0,05)$; кроме того, у них оказалась выше частота субкомпенсированных нарушений. Изменения плодово-плацентарного кровотока при преэклампсии средней степени тяжести наблюдали у 20 (66,67 $\pm 8,61 \%)$ пациенток, только у 1 (3,33 $\pm 3,28 \%)$ женщины в виде изолированной формы и у 21 (70 $\pm 8,37 \%)$ беременной в сочетании с нарушением материнско-плодового кровотока. Обращали на себя внимание более высокий, чем при преэклампсии легкой степени, показатель субкомпенсированных нарушений плодово-плацентарного кровотока, а также 3 ( $10 \pm 5,48 \%)$ случая декомпенсированного нарушения плодово-плацентарного кровотока.

При преэклампсии тяжелой степени у всех 20 (100\%) пациенток сочетались нарушения маточно-плацентарного и плодово-плацентарного кровотоков с высокой, в сравнении с преэклампсией средней степени тяжести, частотой выявления субкомпенсированных и декомпенсированных нарушений.

Изменение гемодинамики в плодово-плацентарном бассейне при преэклампсии средней степени тяжести не могло не сказаться на внутриутробном состоянии плода, что нашло отражение в показателях биофизического профиля плода (БПП). Для беременных с преэклампсией средней степени тяжести наиболее характерной была оценка БПП от 6 до 8 баллов - 23 (76,67 „7,72\%), что соответствовало удовлетворительному и сомнительному состояниям внутриутробного плода. У 13 (65 \$10,67\%) беременных с преэклампсией тяжелой степени оценка БПП была ниже 6 баллов, что привело к досрочному родоразрешению. Нарушения плодово-плацентарной гемодинамики и, как следствие, кислородное голодание были реализованы в снижении реактивности сердечной деятельности плода (влияние «молодых» центров регуляции - задний гипоталамус, мозжечок), затем снижались дыхательная и двигательная активность плода и тонус плода, что отражало стадийность гипоксических повреждений в соответствии c grandual hypoxia concept A.M. Vintsileos (1987).

\section{ВЫводы}

Метаболизм МСТ при гестозе характеризуется преобладанием его деструкции над синтезом, происходящим в условиях десицита эссенциального компонента для синтеза ГАГ $\mathrm{N}$-ацетилглюкозамина. При преэклампсии выявлен дисбаланс во фрракционном составе сульфратированных ГАГ, прогрессирующий соответственно степени тяжести гестоза. Дисбаланс выражался в нарастающем (со степенью тяжести преэклампсии) дефиците хондроитин-4-сульфата и гепаран сульфата, что может служить маркером фрункционального и структурного повреждения эндотелия сосудов, объяснять типичные нарушения в сосудисто-тромбоцитарном звене гемостаза при гестозе. Если преэклампсия легкой степени сопровождается преимущественно функциональными нарушениями эндотелия, то преэклампсия средней тяжести и тяжелой степени - деэндотелизацией сосудов. Для диагностики эндотелиальной дисфункции при преэклампсии можно использовать метод подсчета числа десквамированных эндотелиоцитов (свыше 5,0 X 104/л) и определить фракционное соотношение сульфатированных ГАГ: хондроитин-4-сульфрата и гепаран сульфата.

Принимая во внимание ключевую роль функционального резерва эндотелия в исходе гестации при гестозе, обязательным компонентом лечебных мероприятий должна стать эндотелийпротекторная терапия, направленная на восстановление соединительнотканного матрикса сосудистой стенки и гликокаликса эндотелия.

\section{ЛИТЕРАТУРА}

1. Малышева О.В., Мозговая Е.В., Демин Г.С. и др. //Ассоциация полиморфных аллелей генов ACE и еNOS с развитием гестозов /Медицинская генетика. - 2003. - № 2. - С. 78-82.

2. Блощинская И.А. Вазорегулирующая функция сосудистого эндотелия при фризиологической беременности и гестозе /М.А. Блощинская, Т.А. Петричко //Журнал акушерства и женских болезней. 2003. - Т.12, Вып.1. - С. 26-31

3. Вигівська Л.А. Визначення фактора Віллебранда з метою прогнозування тяжкості пре еклампсії у вагітних групи ризику /Л.А. Вигівська //Проблемы, достижения и преспективы развития медико-биологических наук и практического здравоохранения. - 2007. - Т.143. - С. 35-37. вития медико-биологических наук и практического здравоохранения. - 2007. - Т.143. - С. 35-37.
4. Бразак А.З. , Шевцова А.И., Письменецкая И.Ю. / Гликодиагностика: достижения и 4. Бразак А.З., Шевцова А.И., Письменецкая И.Ю. / Гликодиагностика: достижения и
перспективы [Біохімічні процеси за патологічних станів та їх корекція: матеріали IX з'їзду Укр. біохім. т-ва. Харків, 24-27 жовт. 2006 р.] - Харків., 2006. - С. 3-4.

5. Гомазков О.А. Эндотелий - «эндокринное дерево» /О.А. Гомазков //Природа. - 2000. №5. - C. 38-46.

6. Гомазкова О.А. Молекулярные и фризиологические аспекты эндотелиальной дисфункции. Роль эндогенных химических регуляторов //Успехи физиологических наук. - 2000.

- T.31, №4. - С. 48-59.

7. Гоніський Я.І. Біохімія людини /Я.І. Гоніський, Т.П. Максимчук - Тернопіль, 2001. - 735 с. 8. Громова А.М. Стан сполучної тканини при прееклампсії /А.М. Громова, К.В. Тарасенко //ПАГ. - 1999. - №6. - С. 96-98.

9. Демин Г.С. Анализ ассоциации полиморфизма генов сосудистой системы и эндотелиальной дисфункции с развитием преэклампсии: Автореф. дис....канд. биол. наук /Г.С. Демин $-\mathrm{M}, 2008 .-25 \mathrm{C}$.

10. Киселева Н.И., Занько С.Н., Солодков А.П. - Дисфуункция эндотелия: эксперим. и клин. исследования [Труды III междунар. науч.-практ. конф. Витебск, 18-20 мая 2004 г.] клин. исследования [Труды
Витебск, 2004.- С. $197-200$.

11. Лукьянов П.А. Современная гликобиология и медицина /П.А. Лукьянов, Н.В. Журавлева //Вестник Дальневосточного отделения РАН. - 2004. - Вып.3. - С. 24-34.

12. Малая Л.Т. Эндотелиальная дисфункция при патологии сердечно-сосудистой системы /Л.Т. Малая, А.Н. Корж, Л.Б. Балковая - Харьков: Форсинг, 2000. - 432 с.

13. Манасова Г.С. О роли эндотелиальных пептидов в патогенезе развития преэклампсии беременных /Г.С. Манасова, Т.А. Стокалюк, Т.А. Дробина //Збірник наукових праць Асоціації акушерів-гінекологів України. - К.: Інтермед, 2004. - С. 570-574.

14. Меньшикова Е. Б. NO и NO-синтетаза в организме млекопитающих при различных функ14. Меньшикова Е. Б. NO и NO-синтетаза в организме млекопитающих при различных функ-
циональных состояниях /E.Б. Меньшикова, Н.К. Зенков, В.П. Реутов //Биохимия. - 2000. - Т.65, Вып.4. - С. 485-503.

15. Милованов А.П. Патология системы мать-плацента-плод [Руководство для врачей] / А.П. Милованов - М.: Медицина, 1999. - 448 с.

16. Никитин В.Н. Возрастная и эволюционная биохимия коллагеновых структур /В.Н. Никитин, С.Э. Пэрский, Л.А. Утевская - К.: Наукова думка, 1977. - 279 с.

17. Мозговая Е.В., Малышева О.В., Иващенко Т.Э. и др. //Полиморсиизм генов, участвующих в регуляции функции эндотелия, и его связь с развитием гестоза /Медицинская генетика. щих в регуляции функции эндотелия

18. Прочан Е. Н. Роль эндотелиальной диссфункции в патогенезе преэклампсии /Е.Н. Прочан //Проблемы, достижения и перспективы развития медико-биологических наук и практического здравоохранения. - 2004. - Т.140. - С.120-124.

19. Серов В. В. Соединительная ткань: функциональная морфология и общая патология /B.В. Серов, А.Б. Шехтер - М., 1981. - 312 c.

20. Слуцкий Л.И. Биохимия нормальной и патологически измененной соединительной 20. Слуцкий Л.И. Биохимия нормальной и патоло

21. Филатова О.В. Взаимодействие давления и потока в регуляции диаметра крупных артериальных сосудов /О.В. Филатова, А.В. Требухов, В.Д. Киселев. - Барнаул: изд-во Алтайского ун-та, 2003. $-137 \mathrm{C}$.

22. Мозговая Е.В., Малышева О.В., Иващенко Т.Э. и др. - Эндотелиальная диссрункция при гестозе. Патогенез, генетическая предрасположенность, диагностика и профилактика [Метод. рекомендации] /С-Пб., 2003. - 24 с.

23. Colorado P.C., Torre A., Kamphaus G. et al. // Anti-angiogenic cues from vascular basement membrane collagen /Cancer Res. - 2000. - Vol.60(9). - P. 2520-2526.

24. Bourin M.C. Glycosaminoglycans and the regulation of blood coagulation. /M.C. Bourin, U. Lindahl //Biochem J. - 1993. - Vol. 289 (Pt 2). - P. 313 - 330.

25. Buhimschi I.A., Saade G.R., Chwalisz K., Garfield R.E. (1998) The nitric oxide pathway in pre-eclampsia: pathophysiological implications. Human Reproduction Update, 4(1): 25-42. 26. Carson D.D. Glycoconjugate synthesis during early pregnancy: hyaluronate synthesis and function. /D.D.Carson, A. Dutt, J.P.Tang //Dev. Biol. - 1987. - Vol.120. - P. 228 - 235.

27. Florian J.A. Heparan sulfate proteoglycan is a mechanosensor on endothelial cells. /J.A. Florian, J.R. Kosky, K. Ainslie //Circ. Res. - 2003. - Vol. 93(10). - P. $136-142$.

28. Li R.H. Nitric oxid in the pathogenesis of vasculas disease /R.H. Li, U. Fostermann //J.Pathol. 2000. - Vol.190, №3. - P. 244-254.

29. Mochizuki S. Role of hyaluronic acid glycosaminoglycans in shear-induced endothelium-derived nitric oxide release /S. Mochizuki, H.Vink, O. Hiramatsu //Am. J. Physiol. Heart. Circ. Physiol. - 2003. Vol.285 (2). - P. $722-726$.

30. Siegel G. Connective tissue: more than just a matrix for cells. Comprehensive human physiology (Greger R, Windhorst U, eds.) /G. Siegel - Berlin - Heidelberg: Springer-Verlag, 1996. P. $173-224$.

31. Pages N., Gogly B., Godeau G. et al. // Structural alterations of the vascular wall in magnesium - deficient mice. A possible role of gelatinases A (MMP - 2) and B (MMP - 9). /Magnes Res. - 2003. - Vol.16 (1). - P. $43-48$

32. Tammi M.I. Hyaluronan and homeostasis: a balancing act. /M.I. Tammi, A.J. Day, E.A. Turley //J. Biol. Chem. - 2002. - Vol.277 (7). - P. 4581 - 4584.

33. Toole B. Glycosaminoglycans in morphogenesis. /B. Toole //ln: Cell Biology of Extracellular Matrix // New-York: Plenum Press. - 1981. - P. $259-294$.

34. Williams K.J. Cell-surface heparan sulfate proteoglycans: dynamic molecules mediating ligand catabolism /K.J. Williams, I.V. Fuki //Curr. Opin. Lipidol. - 1997. - Vol.8 (5). - P. 253 - 262. 